Dorota Malec

Uniwersytet Jagielloński w Krakowie

\title{
Otwarcie spotkania poświęconego pamięci Profesora Stanisława Płazy
}

\section{Opening of a Meeting Dedicated to the Memory of Professor Stanisław Płaza}

\section{Szanowni Państwo,}

Pragnę serdecznie powitać wszystkich na zorganizowanej przez katedry historycznoprawne dwudniowej sesji poświęconej stanowi badań nad dziejami ustroju w Europie. Sesja, która zgromadziła wielu znakomitych referentów, zadedykowana została pamięci osoby wyjątkowej - Pana Profesora Stanisława Płazy. Jego postać bardzo żywo i mocno wpisała się w dzieje Wydziału Prawa i Administracji Uniwersytetu Jagiellońskiego, w dzieje historii prawa, w dzieje wszystkich szczegółowych dyscyplin, którymi Pan Profesor podczas swojego życia naukowego się zajmował.

Nasza sesja objęta została patronatem honorowym Jego Magnificencji Rektora Uniwersytetu Jagiellońskiego oraz Prezydenta Miasta Krakowa, dzisiejsze zaś spotkanie zorganizowane zostało przy wsparciu Krajowej Rady Komorniczej. Bardzo serdecznie dziękuję naszym znakomitym patronom honorowym oraz wszystkim instytucjom, których pomoc przyczyniła się do organizacji konferencji. Dzisiejsze spotkanie zgromadziło bardzo liczne grono uczestników: zróżnicowane, ale połączone poprzez postać Pana Profesora Płazy i jego badania. Wśród przybyłych znajdują się najbliżsi współpracownicy Pana Profesora: pracownicy Katedry Historii Prawa Polskiego, z którą przez całe swoje życie zawodowe był związany; profesorowie Wydziału Prawa i Administracji, którzy współdziałali z Nim w tworzeniu pomyślności Wydziału Prawa i Administracji przez lata pracy Pana Profesora Płazy w Uniwersytecie Jagiellońskim. W posiedzeniu bierze udział Rodzina Pana Profesora: córka, Pani Profesor Elżbieta Płaza, siostra Pana Profesora, liczne grono krewnych, którym dziękuję za przybycie.

Przybyło grono historyków prawa nie tylko z Krakowa, lecz także z innych ośrodków, z którymi bardzo żywo Pan Profesor Płaza współpracował: Pan Profesor Adam Lityński wraz z historykami prawa z Uniwersytetu Śląskiego, z którym Pan Profesor Płaza związany był w okresie jego tworzenia. Był to jedyny okres w Jego życiu, kiedy poświęcał swą aktywność nie tylko Uniwersytetowi Jagiellońskiemu. O zasługach organizacyjnych Profesora Płazy dla Uniwersytetu Śląskiego zapewne wspomni Pan 
Profesor Lityński. Kolejna ważna grupa to badacze, nie tylko historycy prawa, lecz także znakomici uczeni, którzy podzielali zainteresowania twórcze, badali wątki podobne do tych, jakie badał Pan Profesor Płaza. Jest wśród nas Pan Profesor Edward Opaliński, przykład takiego właśnie historyka humanisty, którego zainteresowania naukowe pozostają w zbieżności z tym, czym zajmował się Pan Profesor Płaza, są przedstawiciele innych ośrodków naukowych z całej Polski.

Nie wszyscy zaproszeni mogli dziś uczestniczyć w naszym spotkaniu, różne obowiązki, ale i stan zdrowia, nie pozwoliły na przybycie do Krakowa. Wszyscy jednak wyrażali szczery żal, że nie mogą z różnych przyczyn tutaj być. Niektórzy z naszych znakomitych zaproszonych gości, jak Pan Profesor Stanisław Salmonowicz, przysłali listy. Jego list zostanie teraz odczytany. 